\title{
Gambaran Pengetahuan dan Keterampilan Dokter tentang Pengisian Penyebab Kematian Medis (Medical Cause of Death) Berdasarkan Standar ICD-10 di RS Tersier di Bandung
}

\author{
Noverika Windasari ${ }^{1}$, Nur Adibah ${ }^{2}$, Chevi Sayusman ${ }^{2}$
}

\begin{abstract}
Abstrak
Penyebab kematian medis perlu dicantumkan pada setiap rekam medis pasien yang meninggal. Dokter di Rumah Sakit berperan penting dalam menentukan sebab kematian medis (medical cause of death). Tujuan penelitian adalah untuk menilai pengetahuan dan keterampilan dokter tentang cara penulisan penyebab kematian medis (medical cause of death) pada rekam medis di RS Tersier di Bandung yang sesuai dengan standar WHO International Classification of Disease (ICD) 10. Penelitian ini berupa studi deskriptif analitik dengan memberikan kuesioner pada dokter klinis di suatu RS Tersier di Bandung untuk menilai pengetahuan dan keterampilan dokter tentang cara penulisan penyebab kematian medis (medical cause of death) dan kesesuaiannya dengan standar WHO ICD-10. Dari total 928 orang dokter klinis, didapatkan 90 sampel. Sampel mewakili setiap departemen/bagian yang terlibat langsung pembuatan penyebab kematian medis di suatu RS Tersier di Bandung. Hasil penelitian ini menunjukkan 58,1\% dokter yang memahami tentang cara penulisan penyebab kematian medis yang benar, sedangkan 41,9\% belum memahami secara teori. Keterampilan dokter dalam mengisi penyebab kematian medis yang benar dan lengkap sebesar 20,7\%, sedangkan $23,3 \%$ mengisi penyebab kematian medis dengan benar namun tidak lengkap. Sebanyak $75,4 \%$ mengisi penyebab kematian yang salah, terutama karena menuliskan kondisi akhir sebelum kematian (terminal events). Masih separuh dokter $(58,1 \%)$ mengetahui cara penulisan penyebab kematian medis yang benar sesuai standar WHO ICD10. Tingkat keterampilan dalam mengisi penyebab kematian medis yang lengkap, masih sangat rendah (20,7\%).
\end{abstract}

Kata kunci: penyebab kematian, standar internasional WHO, ICD-10, rekam medis

\section{Abstract}

The Cause of death needs to be included in every medical record of a deceased patient. Doctors at the Hospital play an important role in determining the cause of death. The objective of this study was to assess the doctor's knowledge and skills on how to write medical cause of death in medical records at Tertiary Hospital in Bandung accordance to WHO Standards International Classification of Disease (ICD) 10. This study was a descriptive analytic study by giving questionnaires to clinical doctors at a Tertiary Hospital in Bandung to assess the knowledge and skills of doctors on how to write medical cause of death and its compliance with the WHO ICD-10 standards. 90 samples were obtained from a total of 928 clinical doctors in theTertiary Hospital in Bandung. The sample represent seach department that involved in making the cause of medical death in a Tertiary Hospital in Bandung. 58.1\% of doctors understood the correct way to write the cause of medical death, while $41.9 \%$ did not understand the theory. The doctor's skill in writing the correct and complete causes of medical death was $20.7 \%$, while $23.3 \%$ filled the cause of medical death correctly but incomplete. $75.4 \%$ doctors fill the cause of the death with the final diagnosis before death (terminal events) instead of the cause of death. The accuracy of writing cause of death in medical records is very dependent on the knowledge and skills of the doctor. Half of the doctors (58.1\%) know how to write the correct cause of death according to WHO ICD-10 standards. The level of skill in filling out completely the causes of medical death in medical records in accordance with the WHO standard ICD-10 is still very low (20.7\%).

Keywords:medical cause of death, WHO international standard, ICD-10, medical record 
Affiliasi penulis: 1. Departemen IImu Kedokteran Forensik dan Medikolegal Fakultas Kedokteran Univesitas Andalas 2. Departemen IImu Kedokteran Forensik dan Medikolegal Fakultas Kedokteran Universitas Padjadjaran

Korespondensi : Noverika Windasari

(windasari@med.unand.ac.id)Hp: 08116663343

\section{PENDAHULUAN}

Pengisian berkas rekam medis yang tepat dan lengkap akan menentukan laporan kesehatan yang baik. Salah satu informasi yang sangat penting dari rekam medis adalah bagian diagnosis penyebab kematian. $^{1,2}$

Menurut Badan Penelitian dan Pengembangan Kesehatan Kementerian Kesehatan RI, penyebab kematian adalah semua penyakit, kondisi atau penyebab cedera yang menyebabkan atau berperan terhadap terjadinya kematian. ${ }^{3}$ Penyebab kematian medis perlu dicantumkan pada setiap rekam medis pasien yang meninggal, terutama untuk kepentingan kesehatan masyarakat, epidemiologi, penelitian, keamanan publik, kedokteran, dan administrasi kesehatan. ${ }^{3,4}$ Dari segi kesehatan, penyebab kematian medis dapat dipakai untuk menghitung angka harapan hidup, angka kematian menurut penyebab dan umur, bahan pertimbangan untuk mengambil keputusan terkait dengan upaya pencegahan, sehingga status kesehatan menjadi lebih baik. ${ }^{5}$

World Health Organization telah menetapkan bahwa International Classification of Disease (ICD)-10 sebagai sistem klasifikasi internasional mengenai penyakit yang harus dipakai oleh seluruh negara anggota, yang bertujuan untuk standarisasi pengelompokan dan pengkodean penyakit dalam sistem pencatatan, analisis dan pelaporan, sehingga dapat dibandingkan baik antar waktu maupun antar tempat. $^{6} \mathrm{Di}$ Indonesia telah ditetapkan dengan Keputusan Menteri Kesehatan RI, No. 50/MENKES/ SK/I/1998, dimana Rumah Sakit dan Puskesmas diwajibkan melaksanakan pengkodean penyakit sebagai pendataan rekam medis. ${ }^{7}$

Standar WHO ICD-10 merekomendasikan penulisan penyebab kematian medis dalam dua bagian. Bagian I (part I) digunakan untuk penyakitpenyakit yang berkaitan dengan urutan dari kejadian langsung menuju kematian. Bagian II (part II) digunakan untuk kondisi yang tidak berkaitan dengan bagian I, namun secara alamiah berkontribusi terhadap kematian. ${ }^{3}$ Dokter di rumah sakit berperan penting dalam menentukan sebab kematian medis (medical cause of death). ${ }^{3,8,9}$

Beberapa kesalahan yang sering terjadi pada penulisan sebab kematian medis pada rekam medis adalah: ${ }^{7}$

- Mekanisme rangkaian penulisan sebab kematian yang tidak berurutan.

- Penulisan causeofdeath dengan mencantumkan terminal events atau kondisi akhir sebelum kematian, misalnya: respiratory distress syndrome, gagal napas (respiratory failure). henti jantung (cardiac arrest), acute liver failure dan multiple organ disfunction.

- Penulisan kondisi sebab kematian yang lebih dari satu pada satu baris/kalimat pada Part I.

- Pada pasien yang telah lama dirawat yang mengalami komplikasi sehingga menyebabkan kematian, terkadang komplikasi tersebut dibuat sebagai underlying cause of death, yang seharusnya dicantumkan adalah penyakit/cedera yang menyebabkannya.

Penulisan proses fungsional maupun struktur penyakit non spesifik dengan multiple possible causes dapat dicantumkan namun hanya sebagai intermediate atau immediate cause of death tidak sebagai underlying cause of death, misalnya: perdarahan gastrointestinal. $^{9}$

Penelitian Karolina et al (2017) tentang penulisan penyebab kematian medis (medical cause of death) pada rekam medis di suatu RS Tersier di Bandung menunjukkan bahwa hanya $72,2 \%$ rekam medis pasien meninggal yang dilengkapi dengan penulisan sebab kematian medis, sedangkan $27,8 \%$ tidak dilengkapi penulisan sebab kematian medis. Dari rekam medis yang disertai penyebab kematian medis, hanya $21,53 \%$ penyebab kematian medis yang sesuai dengan standar WHO ICD-10. Sebaliknya, 78,24\% tidak sesuai dengan standar WHO ICD-10. ${ }^{10}$

Penelitian ini bertujuan untuk menilai pengetahuan dan keterampilan dokter tentang cara penulisan penyebab kematian medis (medical cause of death) pada rekam medis di suatu RS Tersier di Bandung yang sesuai dengan standar WHO ICD-10. 


\section{METODE}

Penelitian ini berupa studi deskriptif analitik dengan memberikan kuesioner kepada dokter-dokter klinis yang sedang menjalani pendidikan spesialis (PPDS) di Suatu RS Tersier di Bandung untuk menilai pengetahuan dan keterampilan dokter tentang cara penulisan penyebab kematian medis (medical cause of death) dan kesesuaiannya dengan standar WHO ICD-10.

Populasi pada penelitian ini adalah dokter klinis dari seluruh departemen/bagian yang terlibat langsung dalam pengisian penyebab kematian medis di Suatu RS Tersier di Bandung. Jumlah sampel diambil berdasarkan rumus Slovin dengan tingkat kepercayaan 90\%. Dari total 928 orang dokter klinis, didapatkan 90 sampel (responden). Pemilihan responden dilakukan secara acak, yang mewakili setiap departemen/bagian yang terlibat langsung dalam pengisian penyebab kematian medis di Suatu RS Tersier di Bandung.

Kuesioner terdiri dari sepuluh pertanyaan, yang mencakup pengalaman dan pengetahuan dokter tentang pengisian penyebab kematian medis (medical cause of death), yang disertai tiga buah ilustrasi kasus, dimana respoden diminta menuliskan penyebab kematian medis berdasarkan ilustrasi kasus yang ada.

Sebelum diberikan kepada responden, kuesioner telah melalui tahap uji awal. Pengujian awal kuesioner dilakukan terhadap tujuh orang responden (di luar sampel) yang diminta mengisi kuesioner. Kemudian, setelah kuesioner direvisi, kembali diujikan terhadap responden yang sama, sehingga diperoleh sepuluh pertanyaan yang siap diujikan kepada 90 sampel.

\section{HASIL}

Total responden berjumlah 90 orang, yang terdiri dari 51 responden (56,7\%) laki-laki dan 39 responden (43\%) perempuan, seperti yang terlihat pada Gambar 1.

\section{Total Responden: 90 Orang}

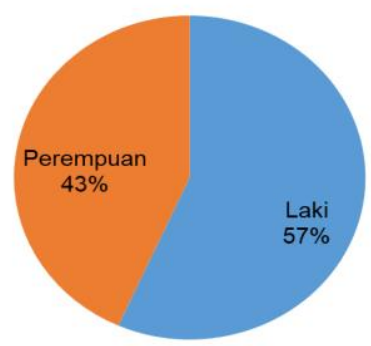

Gambar 1. Distribusi dokter yang menjadi responden

Ada 85 orang (94,4\%) mengaku mengetahui adanya form penyebab kematian medis (medical cause of death) di rekam medis yang harus diisi jika pasien meninggal dan 5 orang $(5,6 \%)$ menjawab tidak mengetahui tentang pengisian penyebab kematian medis tersebut. Jika dinilai dari segi pengalaman, 59 orang (65,6\%) mengaku pernah mengisi form penyebab kematian medis di rekam medis pada pasien yang meninggal, sedangkan sisanya $(34,4 \%)$ belum pernah mengisi form tersebut. Data tersebut diilustrasikan pada Gambar 2.

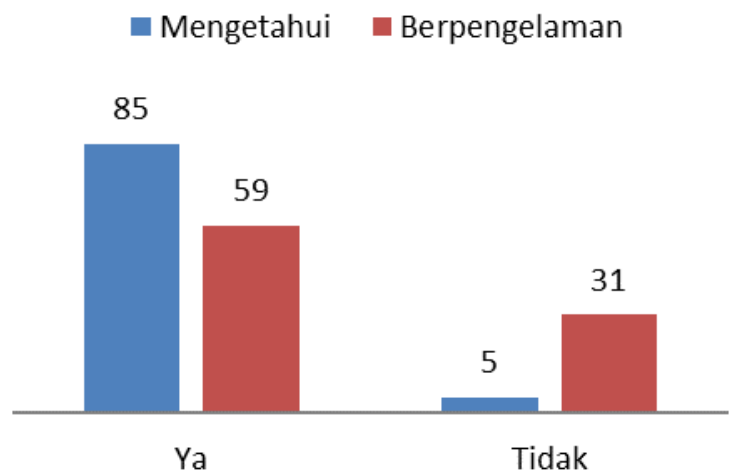

Gambar 2. Pengetahuan dan pengalaman dokter dalam mengisi form penyebab kematian medis

Pada kuesioner terdapat lima buah pertanyaan seputar teori cara penulisan penyebab kematian medis yang dapat menggambarkan tingkat pengetahuan dokter tentang cara penulisan penyebab kematian medis yang benar disesuaikan dengan standar WHO 
ICD-10. Hasil pengolahan data menunjukkan bahwa 52 orang $(58,1 \%)$ dokter yang memahami tentang cara penulisan penyebab kematian medis yang benar, sedangkan 38 orang $(41,9 \%)$ masih belum memahami secara teori.

Kesalahan yang sering dilakukan saat pengisian penyebab kematian medis adalah penulisan cause of death dengan mencantumkan terminal events atau kondisi akhir sebelum kematian, misalnya respiratory arrest, fibrilasi ventrikel, dan asystole. Responden diberikan beberapa pilihan diagnosis penyebab kematian dan diminta untuk menentukan yang mana diagnosis penyebab kematian medis yang sesuai dengan standar WHO ICD-10. Berdasarkan data yang ditampilkan pada Gambar 3, sebanyak 64 orang (71\%) menganggap respiratory arrest boleh dituliskan, 35 orang (38,9\%) membolehkan penulisan fibrilasi ventrikel, dan 18 orang (20\%) membolehkan penulisan asystole sebagai penyebab kematian medis. Sedangkan yang memilih jawaban yang benar (intraabdominal hemorrhage dan myocardial infarction) sebanyak 42 orang $(47,2 \%)$.

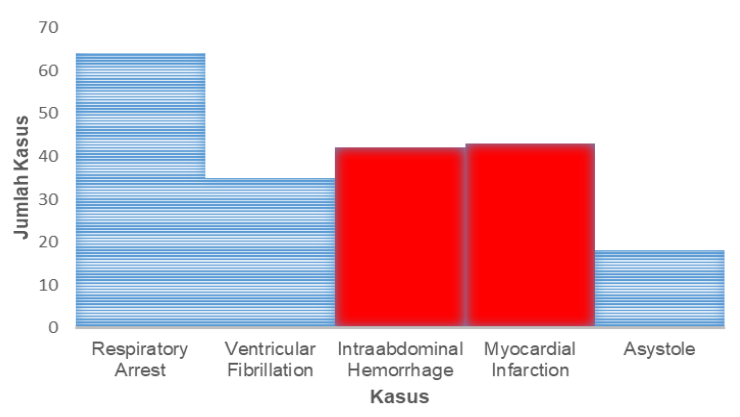

Gambar 3. Diagnosis penyebab kematian medis yang benar menurut responden

Responden diberikan tiga buah ilustrasi kasus, kemudian diminta untuk mengisi penyebab kematian medisnya sesuai standar WHO ICD-10 pada form yang telah disediakan. Tingkat kesulitan ilustrasi kasus terbagi atas ringan, sedang dan berat. Pada ilustrasi kasus pertama (ringan), 31 orang (34,4\%) mengisi penyebab kematian medis dengan benar dan lengkap.
Sebanyak 36 orang (40\%) mengisi penyebab kematian medis dengan benar namun tidak lengkap, 21 orang $(23,3 \%)$ mengisi penyebab kematian medis yang salah, dan 2 orang (2,3\%) tidak menjawab.

Pada ilustrasi kasus kedua (tingkat kesulitan sedang), didapatkan bahwa terdapat proporsi jumlah responden yang hampir sama antara responden yang mengisi penyebab kematian medisnya dengan benar dan lengkap dibandingkan dengan responden yang mengisi penyebab kematian medis dengan benar b19 orang $(21,1 \%)$ dan 18 orang $(20 \%)$, sedangkan lebih dari separuh responden (49 orang atau 54,4\%) mengisi penyebab kematian medis yang salah, dan 4 orang $(4,4 \%)$ tidak menjawab.

Pada ilustrasi kasus ketiga dengan tingkat kesulitan yang lebih tinggi, didapatkan bahwa 71 orang (78,9\%) mengisi penyebab kematian medis yang salah, hanya 6 orang $(6,7 \%)$ yang mengisi penyebab kematian medis dengan benar dan lengkap, 9 orang (10\%) mengisi penyebab kematian medis dengan benar namun tidak lengkap, dan 4 orang $(4,4 \%)$ tidak menjawab.

Berdasarkan ketiga ilustrasi kasus, dapat disimpulkan bahwa keterampilan dokter dalam mengisi penyebab kematian medis yang benar dan lengkap hanya $20,8 \%$, sedangkan $23,3 \%$ mengisi penyebab kematian medis dengan benar namun tidak lengkap. Data mengenai ilustrasi kasus tersebut disajikan pada Tabel 1.

Tabel 1. Ilustrasi kasus tentang keterampilan penulisan penyebab kematian medis

\begin{tabular}{|c|c|c|c|}
\hline Jawaban & Ringan & Sedang & Sulit \\
\hline Benar dan Lengkap & 31 & 19 & 6 \\
\hline Benar dan Tidak Lengkap & 36 & 18 & 9 \\
\hline Salah & 21 & 49 & 71 \\
\hline Tidak Menjawab & 2 & 4 & 4 \\
\hline
\end{tabular}


Tabel 2. Gambaran kesalahan penulisan penyebab kematian medis (medical cause of death)

\begin{tabular}{ll}
\hline $\begin{array}{l}\text { Kesalahan Pengisian Penyebab Kematian } \\
\text { Medis }\end{array}$ & Jumlah \\
\hline Penulisan kondisi akhir sebelum kematian & \\
(terminal events): & 19 \\
- Gagal napas (respiratory failure) & 39 \\
- Henti napas (respiratory arrest) & 37 \\
- Henti jantung (cardiac arrest) & 3 \\
- Aritmia & 9 \\
- Fibrilasi ventrikel & \\
Urutan Cause of Death yang terbalik & 6 \\
Diagnosis lainnya & 29 \\
\hline Total & 142 \\
\hline
\end{tabular}

Didapatkan 142 total kesalahan penulisan penyebab kematian medis, yang tidak sesuai standar WHO ICD-10. Seperti yang terlihat pada Tabel 2, sebesar $75,4 \%$ kesalahan pengisian penyebab kematian medis terutama terletak pada penulisan kondisi akhir sebelum kematian (terminal events), diantaranya gagal napas (respiratory failure), henti napas (respiratory arrest), henti jantung (cardiac arrest), aritmia, dan fibrilasi ventrikel. Kesalahan pengisian lainnya terletak pada pengisian penyebab kematian medis yang tidak berurutan (terbalik) sebesar 6 jawaban (4,2\%) dan penulisan diagnosis lain sebesar $20,4 \%$.

\section{PEMBAHASAN}

Berdasarkan hasil penelitian, dapat disimpulkan bahwa pengetahuan dan keterampilan dokter klinis di RS Tersier di Bandung dalam pengisian penyebab kematian medis (medical cause of death) di rekam medis masih perlu ditingkatkan. Dokter yang mengetahui cara penulisan penyebab kematian medis yang benar sesuai standar WHO ICD-10 baru sebesar $58,1 \%$. Ketrampilan dokter dalam mengisi penyebab kematian medis yang benar dan lengkap hanya $20,7 \%$, sedangkan $23,3 \%$ mengisi penyebab kematian medis dengan benar namun tidak lengkap. Hal ini sesuai dengan penelitian tentang pengisian penyebab kematian medis pada rekam medis pasien yang meninggal di suatu RS Tersier di Bandung, dimana hanya $21,53 \%$ penyebab kematian medis yang sesuai dengan standar WHO ICD-10. Penelitian Karolina et al (2017) tersebut menunjukkan bahwa terdapat rendahnya ketepatan pengisian penyebab kematian medis pada rekam medis jenazah berbanding lurus dengan tingkat keterampilan dokter dalam mengisi penyebab kematian medis yang sesuai dengan ICD$10 .^{10}$

Kesalahan penulisan paling banyak disebabkan oleh penulisan terminal events sebagai rangkaian penyebab kematian. Kesalahan dalam penulisan penyebab kematian medis juga dipengaruhi oleh tingkat pengetahuan dokter tentang pengisian penyebab kematian medis menurut WHO ICD-10.

\section{SIMPULAN}

Kesalahan yang sering dilakukan saat pengisian penyebab kematian medis adalah penulisan cause of death dengan mencantumkan terminal events atau kondisi akhir sebelum kematian.

\section{SARAN}

Penelitian lanjutan untuk menilai faktor-faktor apa saja yang mempengaruhi tingkat pengetahuan dan keterampilan dokter dalam pengisian penyebab kematian medis (medical cause of death) yang sesuai standar WHO ICD-10 pada rekam medis terutama di Suatu RS Tersier di Bandung. Selain itu, pihak rumah sakit perlu membuat aturan yang tegas untuk dokter klinis mengenai kewajiban melengkapi dan menulis sebab kematian medis pada rekam medis sesuai dengan standar WHO ICD-10. Sosialisasi/pelatihan secara berkala pada dokter-dokter rumah sakit, terutama PPDS mengenai penulisan penyebab kematian medis juga diperlukan untuk meningkatkan pengetahuan dan keterampilan dokter mengenai tata cara penulisan sebab kematian medis sesuai dengan standar WHO ICD-10.

\section{DAFTAR PUSTAKA}

1. Kementerian Kesehatan RI. Rekam medis. Permenkes Nomor 269/Menkes/PER/III/ 2018. Kementerian Kesehatan RI.

2. Nuryati, Hidayat T. Evaluasi ketepatan kode diagnosis penyebab kematian berdasarkan ICD10 di RS Panti Rapih Yogyakarta. Jurnal Manajemen Informasi Kesehatan Indonesia. 2014 Mar;2:82-8. 
3. Badan Penelitian dan Pengembangan Kesehatan. Buku panduan penentuan kode penyebab kematian menurut ICD-10: panduan untuk dokter. Jakarta: Kementerian Kesehatan $\mathrm{RI} ; 2016$.

4. Hanzlick R. Cause of death and the death certificate. Northfield: College American Pathologists; 2006.

5. Anonym. Klasifikasi statistik internasional tentang penyakit dan masalah kesehatan (ICD-10). Surabaya: KPRI RSUD. Dr. Soetomo Surabaya; 1998.

6. World Health Organization (WHO). ICD-10 international statistical classifcation of diseases and related health problems 10 th revision volume 2 instruction manual. Geneva: WHO; 2004.

7. Departemen Kesehatan. Pemberlakuan statistik internasional mengenai penyakit revisi kesepuluh. Jakarta: Departemen Kesehatan RI; 1998.
8. Kementerian Kesehatan RI. Pedoman pengisian surat keterangan kematian (SKK): panduan untuk dokter rumah sakit dan puskesmas. Jakarta: Badan Penelitian dan Pengembangan Kesehatan Kementerian Kesehatan Rl; 2016.

9. Qaddumi JA, Nazzal Z, Yacoub A, Mansour M. Physicians' knowledge and practice on death certification in the North West Bank, Palestine: across sectional study. BMC Health Services Research. 2018;18(8):1-6.

10. Karolina A, Windasari N, Sayusman C. Perbandingan penyebab kematian medis (medical cause of death) berdasarkan standar ICD 10 di RSUP Dr Hasan Sadikin Bandung. Pekanbaru: Prosiding pertemuan ilmiah tahunan perhimpunan dokter forensik Indonesia; 2017. [diunduh 2018 Apr 24]. Tersedia dari: http://fk.unri.ac.id/prosiding-pertemuan-ilmiahtahunan-2017-pdfi/3-aberta-karolina-noverikawindasari-chevi-sayusman/ 